\title{
Література:
}

DRUŽYNEC', M.L.: Ukrajins'ke usne movlennja: psycho- ta sociofonetyčnyj aspekty. Odesa, 2019. $580 \mathrm{~s}$.

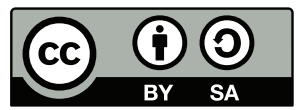

This work can be used in accordance with the Creative Commons BY-SA 4.0 International license terms and conditions (<https://creativecommons.org/licenses/by-sa/4.0/legalcode>). This does not apply to works or elements (such as images or photographs) that are used in the work under a contractual license or exception or limitation to relevant rights.

https://doi.org/10.5817/OS2021-2-9

\section{Регионы России в парадигме антропоцентризма, лингвокультурологии и культурной географии}

CINGEROVÁ, N. - DULEBOVÁ, I.: Kultúrne regióny Ruska. Bratislava: Univerzita Komenského v Bratislave, 2021. 200 s. ISBN 978-80-223-5113-3.

В рецензируемом нами вузовском учебнике Kultúrne regióny Ruska, написанном в рамках грантового проекта KEGA 052UK-4/2018: Vysokoškolská učebnica Kultúrne regióny Ruska v cestovnom ruchu - Н. Цингерова, - кандидат филологических наук, доцент кафедры русистики и восточноевропейских исследований Философского факультета Университета им. Коменского в Братиславе, вместе с соавтором И. Дулебовой, кандидатом филологических наук, доцентом из одноимённой кафедры, предлагают вниманию студентов и более широкой научной общественности новый вузовский учебник, затрагивающий проблематику культурных регионов России. Цель авторов - предложить подходящий материал не только для учебных программ словацких вузов, специализирующихся на туризме и восточнославянских исследованиях, но также и для будущих учителей, преподавателей и переводчиков. В своём учебнике авторы представляют учебный материал на основе своих лекций и семинаров со студентами в стенах Университета им. Коменского в Братиславе. Считая региональный аспект самым важным, замыслом Н. Цингеровой и И. Дулебовой является более комплексный взгляд на существенную специфику разнообразных образов России и судьбы её регионов. Положительно оцениваем тот факт, что авторы своё внимание не сосредоточивают только на двух наиболее известных «столицах». Контекстуализацией исторических и культурных 
памятников России Н. Цингерова и И. Дулебова соответствующим образом расширяют диапазон, указанной в библиографии русской научной литературы, в которой подчёркивается, в первую очередь, развитие словарного запаса из сферы туризма в целом, знакомство с реалиями Российской Федерации, что отражается в координатах классического страноведения.

На наш взгляд, авторы правильно учитывают требования применения знаний студентов после окончания учёбы в том плане, что составленный ими словник и учебник будут соответствующим образом способствовать повышению профессиональной компетентности студентов, а также будут мотивировать к узнаванию и представлению России во всем многообразии.

Методологической базой рецензируемого нами учебника является взаимный образовательный процесс, направленный на обучение иностранному языку посредством фактов о культуре страны, а также усваивание знаний о культуре страны на иностранном языке, так называемый «язык через культуру, культура через язык» (с.6). Можно вполне согласиться с мнением Н.Цингеровой и И.Дулебовой о принадлежности этого принципа «к главным векторам современной лингводидактики в университетской среде» (там же).

При отборе и обработке темы Н. Цингерова и И. Дулебова соответственно учли тот факт, что сама Россия многообразна. Поэтому Россию популяризируют в качестве мультинационального и мультиконфесионального государства, состоящего из разнообразных регионов, территорий с различными историческими и культурными судьбами. Они в настоящее время проявляются в общественном пространстве в виде достопримечательностей, которые авторы рецензируемого учебника пытались представить студентам в работе Historické a kultúrne pamiatky Ruska. Heslár, изданном коллективом авторов Н. Цингеровой, И. Дулебовой и К.Яловой в 2019 году. В рецензируемом нами учебнике Н. Цингерова и И. Дулебова ставили себе целью поместить эти памятники культуры в более широкий исторический и культурный контекст. Они предполагают, что студенты, усваивая учебный материал, будут работать и с литературными текстами, и с текстами общественного дискурса. Положительно оцениваем решение авторов, что в учебнике они отмечают звёздочкой $\left(^{*}\right)$ те памятники культуры, которые более подробно описаны в вышеуказанном словнике с целью облегчить читателю ориентацию в материале.

На наш взгляд, на основе замечательно составленной концепции учебника читатель может как повысить ареальную, так и культурную, лингвистическую и историческую компетенции. С этим намерением в учебнике представлены тематически соотнесённые тексты не только из российских СМИ, но также из художественной литературы, адаптированные для учебных целей. 
Отбирая материал для составления учебника, Н. Цингерова и И. Дулебова исходили из антропоценрической парадигмы, причём за основу взяли помимо лингвокультурологии и культурную географию, в центре внимания которой находятся исторические и культурные картины страны. На основе этого авторы соответствующим образом решили представить и задания к отдельным темам с целью привлечь внимание студентов к концептуализации страны и её культурам на основе литературных текстов и отрывков из общественного дискурса, а также к предлагаемым темам семинарных работ.

Представленный вузовский учебник Н. Цингеровой и И. Дулебой отличается чёткостью композиции и продуманной структурой. Он состоит из четырёх глав, а также содержит предисловие (с. $5^{-8)}$, проекты семинарных работ (с. 172-173), список литературы (с. 174-192) и использованный иллюстративный материал (с. 193-199). Можно положительно оценить то, что основные тексты каждой главы учебника соответствующим образом дополняют тщательно подобранные чёрно-белые и цветные фотографии, картины, открытки и карты. В каждой главе также имеется дополнительный лингвокультурологический, страноведческий и другой комментарий, подобранный из разных электронных или других источников, и, таким образом, облегчающий читателю понимание фактов, событий и реалий, упоминаемых в соответствующей главе.

В первой главе (Základná geografická charakteristika) Н. Цингерова и И. Дулебова вводят читателя в пространство России и дальше знакомят его с растительным миром.

В вводной части второй главы (L’udia a sidla) авторы освещают основные проблемы демографии и миграции. В первом подразделе речь идёт об урбанизации России в диахронном и синхронном аспектах, во втором подразделе отмечается проблематика типов российских городов, южных крепостей, сибирских и закрытых городов - наукоградов. В третьем подразделе освещаются вопросы плотности населения.

В третьей главе учебника (Rusko ako multinárodnostný a multilingválny štát) Н. Цингерова и И. Дулебова представляют Россию как мультинациональное и мультилингвальное государство, акцентируя внимание на этносах Российской Федерации согласно языковым семьям, этническому принципу в административном делении страны (подраздел 3.1) и этнокультурном туризме (подраздел 3.2). В подразделе 3.3 речь идёт о писанницах и могилах, так называемых курганах.

В четвёртой главе (Rusko ako multikonfesionálny štát), являющейся самой объёмной главой учебника, авторы знакомят читателя с Россией как мультиконфессиональным государством, рассматривая не только религиозное дифференцирование в период царской России, а также на советском 
и постсоветском пространстве. Подраздел 4.1 посвящён вопросам православия. В рамках данного подраздела затрагивается специфика периода до монголо-татарского ига (внимание сосредоточивается на храмах новгородской боярской республики и владимиро-суздальского княжества). Дальше речь идёт о сакральном искусстве 14-16 веков, где приводится понятие о храмах московского кремля (Успенский собор, Сретенский монастырь, Архангельский собор, Благовещенский собор, Церковь Положения ризы пресвятой Богородицы, Храм Василия Блаженного и Троицкая церковь). Много места также отводится средневековому сакральному изобразительному искусству Новгорода, Пскова и Москвы. Далее речь идёт о монастырской колонизации Севера и о монастырях-крепостях Москвы. Затем говорится о влиянии Запада в России, т. е. внимание сосредоточивается на проникновение стилей барокко (московское, петербургское и сибирское барокко) и классицизма. Освещается и псевдорусский стиль в архитектуре с двумя примерами храмов, построенных в Москве (Храм Христа Спасителя) и в Санкт-Петербурге (Спас на Крови).

В последующих трёх отдельных подразделах (4.2, 4.3 и 4.4) много места отводится проблематике ислама (ареал среднего Поволжья и ареал Северного Кавказа), буддизма и иудаизма в России.

Подводя итог сказанному, можно отметить, что при разработке рецензируемого учебника авторы использовали адекватную методологию и правильно организовали композицию. Таким образом, они представили студентам-филологам наглядную и доступную публикацию. Актуальная и современная разработка данного учебника представляет собой выдающийся труд Н. Цингеровой и И. Дулебовой, которые обогатили словацкий книжный рынок со сравнительно узким кругом оригинальных учебников, посвящённых культуре, истории и географии России. Хочется также отметить, что уже в настоящее время со дня своего издания (в начале этого календарного года) публикация, безусловно, нашла своих первых адресатов. Этот ценный и профессионально составленный вузовский учебник, вызывающий положительное впечатление, заслуживает своего места и надлежащего внимания среди других похожих публикаций.

Таким образом, в заключение следует отметить, что данный учебник написан соответствующим научным и одновременно доступным языком и, в целом, без сомнения, представляется актуальной и серьёзной работой, который может помочь студентам при развитии их ареальной, культурной, языковой и исторической компетенций.

Ян Галло 


\section{Литература:}

CINGEROVÁ, N. - DULEBOVÁ, I.: Kultúrne regióny Ruska. Bratislava: Univerzita Komenského v Bratislave, 2021. 200 s. ISBN 978-80-223-5113-3. CINGEROVÁ, N. - DULEBOVÁ, I. - JALOVÁ, K.: Historické a kultúrne pamiatky Ruska. Heslár. Bratislava: Stimul. 2019. [online]. [cit. 24. 5. 2021]. <http://stella.uniba.sk/ texty.FiF_NCIDKJ_pamiatky_heslar.pdf>.

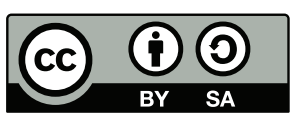

https://doi.org/10.5817/OS2021-2-10

\section{Jak jsou tvořena pojmenování kulturních rostlin v slovinských nářečích ${ }^{1}$}

KUMIN HORVAT, M.: Besedotvorni atlas slovenskih narečij. Kulturne rastline. Ljubljana: ZRC SAZU, 2018. ISBN 978-961-05-0088-9.

Slovinská jazykovědkyně Mojca Kumin Horvat se ve své knize Besedotvorni atlas slovenskih narečij. Kulturne rastline věnuje slovotvorným a lexikálním rozdílům nářeční slovní zásoby z okruhu kulturní rostliny. Zpracovává nářeční pojmenování planých ovocných stromů, nadzemních částí krmných plodin, druhů slámy, ovocných moštů a ovocných pálenek. Podkladem knihy byla autorčina disertační práce Morfološka struktura in geolingvistična interpretacija rastlinskih poimenovanj $v$ slovenskih narečjih $\mathrm{z}$ roku 2012.

Kniha formátu A4 sestává z 263 stran. Po obsahu následuje předmluva a úvod, dále šest kapitol. Knihu uzavírá seznam použité literatury, seznam zkratek a značek, soupis map a materiálových indexů a tabulka s naznačenou slovotvornou strukturou analyzovaných lexémů. $\mathrm{V}$ samém závěru knihy najdeme abecední rejstřík všech nářečních podob.

První kapitola Metody prípravy materiálu na s. 13 podává informace o materiálové základně. $\mathrm{V}$ knize $\mathrm{v}$ porovnání s disertační prací byla zhuštěna sít zkoumaných

1 Tento příspěvek vznikl s podporou dlouhodobého koncepčního rozvoje Ústavu pro jazyk český AV ČR, v. v. i., RVO: 68378092. 